Article

\title{
Corporate Social Responsibility and Business Philosophies among Hungarian Business Students
}

\author{
László Berényi ${ }^{1, *}$ and Nikolett Deutsch ${ }^{2}$ (1) \\ 1 Department of Public Management and Information Technology, University of Public Service, \\ 1083 Budapest, Hungary \\ 2 Institute of Business Development, Corvinus University of Budapest, 1093 Budapest, Hungary; \\ nikolett.deutsch@uni-corvinus.hu \\ * Correspondence: berenyi.laszlo@uni-nke.hu
}

check for updates

Citation: Berényi, L.; Deutsch, N. Corporate Social Responsibility and Business Philosophies among Hungarian Business Students. Sustainability 2021, 13, 9914. https://doi.org/10.3390/ su13179914

Academic Editor: Antonio Boggia

Received: 14 August 2021

Accepted: 31 August 2021

Published: 3 September 2021

Publisher's Note: MDPI stays neutral with regard to jurisdictional claims in published maps and institutional affiliations.

Copyright: (c) 2021 by the authors. Licensee MDPI, Basel, Switzerland. This article is an open access article distributed under the terms and conditions of the Creative Commons Attribution (CC BY) license (https:/ / creativecommons.org/licenses/by/ $4.0 /)$.

\begin{abstract}
This study attempts to identify a relationship between the perception of corporate social responsibility (CSR) and the business philosophies (Machiavellianism, moral objectivism, legalism, ethical relativism, social Darwinism) among Hungarian business students. The goals of the investigations are (1) to explore the perception of CSR, (2) to analyze which business philosophies describe the students, and (3) to characterize typical patterns by means of cluster analysis. The data collection was performed by means of a self-administered, voluntary online survey including the Attitudes Toward Business Ethics Questionnaire (ATBEQ) instrument. Grouping effects were tested with non-parametric analysis of variance; cluster analysis used the K-Means method. The research sample consisted of 865 responses. Machiavellianism was found to be the most dominant business philosophy among the respondents. The cluster analysis shows three patterns, namely (1) CSR believers, (2) large business-oriented, and (3) skeptic. The correlations between CSR perception and business philosophy scores confirm the relationship assumed. The understanding of the value system of the students allows targeted curriculum development for the higher education institutions and, as a result, a more effective approach to CSR applications. Moreover, the result on business philosophies itself provides a contribution to cross-national contribution in the field. Future research should include the extension of the analysis to other students and business practitioners.
\end{abstract}

Keywords: CSR perception; ATBEQ; business ethics; business philosophies; business students

\section{Introduction}

The path of development from the first definitions of sustainability in the 1980s [1] to the complex structure of the Sustainable Development Goals [2] suggests the comprehensive nature of the topic with several research opportunities [3]. Since the topics are closely related to each other [4], it may be easier to find successful paths to development. Companies have a crucial role both in causing and solving problems [5]. Corporate social responsibility (CSR) became a popular topic covering the related issues. It can be considered as the company-level response to sustainability, since it incorporates stakeholder values and interests in business [6]. Friedman's approach, dictating that a company's only responsibility is to its shareholders [7], is a focus point for a debate even 50 years later. Companies keep in mind that the business of business is business, but based on double value creation [8], shareholder value is only available through customer value. CSR became a link between business strategy and sustainable development [9].

Accepting that CSR is an inevitable ingredient of today's companies, challenges arise in specifying the content and operating it appropriately. The approach to CSR must be explored beyond the diverse scope of CSR to answer these challenges. CSR cannot help to achieve a higher level of sustainability and coordinate initiatives in this field if it is subject only to the increase in profit, it is for greenwashing purposes, or the implementation costs exceed the benefits available. 
However, CSR actions can be understood as corporate decisions, paying attention to different interests and values. The knowledge and values of the decision-makers are reflected in the design and implementation of the actions; even then, corporate rules and institutions set boundaries. Training the present and future generations of these decision-makers may help in achieving sustainability through more effective CSR actions in any respect.

This study contributes to the knowledge base of understanding CSR in Hungary among higher education students. The research is limited to the investigation of business students in higher education. Although such investigations cannot offer a comprehensive answer to all business challenges, focusing on business students is relevant. The role of these students is prominent since, within a few years, they will act as decision-makers of companies. Shaping their knowledge during the studies allows the successful and efficient contribution to achieving CSR and sustainability goals. Getting to know their opinions about the role and opportunities about CSR, a targeted curriculum can be established that allows a more favorable managerial behavior. Examining the attitudes towards business ethics and the opinions about the role of CSR of business students is used for finding patterns in favor of building proper development strategies.

The complex and diversified interpretation of CSR requires extensive research activities to understand the motivations and mechanisms in the field. A better understanding of the attitudes toward CSR is supposed by the personal value system represented by the business philosophies. The goal of this study is to explore the connection between the approach to CSR and the scores of business philosophies among Hungarian higher education students. Three research questions were formulated:

- RQ1: What do Hungarian business students think about CSR?

- RQ2: Which business philosophies characterize Hungarian business students?

- RQ3: What patterns of opinions about CSR can be identified based on the business philosophies?

The structure of the paper is as follows. Section 2 presents a literature review on the ethical perspectives of CSR and business philosophies. Section 3 shows the research design and sample characteristics. Section 4 summarizes the results, supplemented with Appendices A and B. Section 5 discusses the results, and Section 6 concludes the findings.

\section{Literature Review}

\subsection{Ethical Aspects of CSR}

An early definition of the social responsibility of a businessman by Bowen [10] emphasized the ethical aspects of the decisions to social expectations and values. The ethical side appears in the definition of the ISO 26000 standard [11], which defines it as the "responsibility of an organization for the impacts of its decisions and activities on society and the environment, through transparent and ethical behavior". The ethical approach means that a company establishes a CSR policy because it perceives CSR as a moral duty [12], but this must be consistent with the business' interest at the same time. One driver of CSR is reputation [13], but it can be derived from public pressure. CSR reporting is a tool for influencing social judgment and company value, so the potential for abuse should not be overlooked. A lack of independent verification of CSR report data needs special attention [14]. Bhatia and Makkar [15] highlighted that the developing economies show a higher incidence of CSR disclosure.

CSR itself is constantly evolving from a philanthropic shape to compliance with stakeholders. Moreover, CSR has primarily been treated as a corporate issue for enhancing performance, but nowadays, it is driven by ideological thinking and multi-faced business, increasing the power and positive force of corporations [16]. Dahlsrud [17] has identified 37 definitions of CSR in 2006. Fassin et al. [18] underlined that unclear semantics and specialist terminology and concepts are continuously mixed up in terms of context, content, and perspectives. De Bakker et al. [19] emphasized the marketing labels dreamed up by consultants and new concepts launched by academics in amplifying the confusion. The 
challenges for the 21st century are refinements, research, alternative themes, management practices, and global expansion summarized by Carroll [20]. It is not the objective of this paper to review the development of CSR and related concepts in detail.

As a highlight, the change in the EU's definition of CSR acts against a purposeful and differentiated approach. According to the former wording, CSR "is a concept whereby companies integrate social and environmental concerns in their business operations and in their interaction with their stakeholders on a voluntary basis" [21]. The 2011-14 CSR strategy formulated a more comprehensive definition as "the responsibility of enterprises for their impacts on society" [22]. Neither of the two definitions emphasize going beyond the direct business interest, and even CSR's voluntary nature is out of their scope. The missing voluntary nature of the definition allows for governmental regulation, but it can also lead to a tangled interpretation of the companies' actions.

McAleer [23] disputed the Friedman doctrine, according to which companies are artificial legal constructions, and so their responsibilities are artificial and cannot be moral. Regardless of whether moral responsibility is attributed only to people or companies, the values and attitudes of the decision-makers can promote or inhibit CSR efforts.

Moral or ethical characteristics are included in each CSR approach, and the concepts are interrelated [24]. Ethics determines whether a person will act or behave in a fair manner [25].

\subsection{Business Philosophies}

The analysis of the business philosophies is based on the work of Stevens [26], Miesing and Preble [27], and Neumann and Reichel [28]. In line with the instrument of the data collection, five of the philosophies are discussed. Clark et al. [29] described the five philosophies concisely as follows:

- "Machiavellianism: Business firms are a self-contained organism with its own 'natural laws' which can be bent but not broken.

- Ethical relativism: Deals with feelings and attitudes and is based on social convention, which accepts behavior sanctioned by established group norms. Hence, moral good means conforming to the way things are in a given time and place and selfishness becomes the root of all evils.

- Legalism: Doing an action or series of actions defensively out of a sense that doing it this way will promote the impression that a practitioner is 'thorough' and 'covered' from an imagined legal point of view.

- Social Darwinism: Individuals, by pursuing their own selfish interests, unwittingly and effectively promote the social welfare. Businesses survive because they obey the natural laws of competition.

- Moral objectivism: The moral guide is rational self-interest which includes the right to defy fate by making rational decisions which lead to productivity and happiness." [29] (p. 127).

The ethical-moral nature of CSR assumes the personal responsibility of people. An amoral approach or acceptance of immorality can be assumed behind the misunderstandings and various attitudes toward CSR. Considering the pyramid model of Carroll [25], moral considerations appear on higher levels. Miesing and Preble [27] highlighted that Machiavellianism is amoral, since the outcome justifies the way to access it. Social Darwinism is also amoral, because the laws of evolution and selection are not amendable by man. Of course, if an amoral business philosophy can describe someone, it does not mean incompatibility with a CSR action, but the driving forces may be limited to economic interests.

\subsection{ATBEQ Studies}

There are several instruments developed for measuring personal attitudes to ethics [30]. One of these, the Attitudes Toward Business Ethics Questionnaire (ATBEQ) is an instrument oriented towards attitudes on selecting business ethics situations [31,32]. The curiosity of ATBEQ is that it is specially applied for business students worldwide. It is a commonly 
accepted research instrument in social and management science [32]. Therefore, it can be used for several purposes. The main findings of relevant studies that use the instrument are summarized in Table 1. These studies focus on cultural issues and international comparison of the ATBEQ results. Some of the authors suggest alternative factor structures. The present study is a novel experiment in terms of the joint examination of business philosophies and CSR perception.

Table 1. Review of empirical research using ATBEQ.

\begin{tabular}{|c|c|c|c|}
\hline Authors & Countries Involved & Sample Size & Findings \\
\hline $\begin{array}{l}\text { Preble and Reichel, } \\
1988 \text { [31] }\end{array}$ & United States, Israel & $\begin{array}{l}129 \text { US and } 150 \text { Israeli } \\
\text { students }\end{array}$ & $\begin{array}{l}\text { Few statistically significant differences between the two } \\
\text { countries. This paper lays down the methodology of } \\
\text { subsequent analyses. }\end{array}$ \\
\hline Small, 1992 [33] & Western Australia & 272 students & $\begin{array}{l}\text { Similar results to the U.S. and Israeli students, supporting } \\
\text { the view that business ethics and practices are similar in } \\
\text { the Western world. }\end{array}$ \\
\hline $\begin{array}{l}\text { Moore and Radloff, } \\
1996[34]\end{array}$ & South Africa & 379 students & $\begin{array}{l}\text { Significant differences between the countries. Suggestion } \\
\text { for revised ATBEQ questions. }\end{array}$ \\
\hline $\begin{array}{l}\text { Sims and Gerez, } \\
2004[35]\end{array}$ & $\begin{array}{l}\text { Turkey and former results of } \\
\text { other studies }\end{array}$ & 125 Turkish students & $\begin{array}{l}\text { Corruption Perceptions Index and Hofstede model } \\
\text { involved. Ethics are not as strong a } \\
\text { component of the business environment for } \\
\text { Turkey as they are for the United States and for Western } \\
\text { Australia. }\end{array}$ \\
\hline $\begin{array}{l}\text { Kum-lung and } \\
\text { Teck-Chai, } 2010 \text { [36] }\end{array}$ & Malaysia & 269 students & $\begin{array}{l}\text { Intrapersonal religiosity is a significant determinant in } \\
\text { business ethics attitudes, but interpersonal religiosity is not. } \\
\text { No significant difference by gender in the total sample. } \\
\text { Study level correlates with attitude to business ethics }\end{array}$ \\
\hline $\begin{array}{l}\text { Begeac, Furrer and } \\
\text { Reynaud, } 2010 \text { [37] }\end{array}$ & France, Romania & $\begin{array}{l}102 \text { French and } 118 \\
\text { Romanian students }\end{array}$ & $\begin{array}{l}\text { Cross-national comparison. Machiavellianism is more } \\
\text { characteristic to Romanian students; moral objectivism and } \\
\text { social Darwinism scores are higher among French. } \\
\text { Religion does not show significant differences. }\end{array}$ \\
\hline $\begin{array}{l}\text { Price and van der Walt, } \\
2013 \text { [38] }\end{array}$ & South Africa & 147 students & $\begin{array}{l}\text { Managers more readily accepting that any "legitimate" } \\
\text { action is "right". } \\
\text { Attitudes towards business ethics have changed } \\
\text { significantly over twenty years in South Africa. }\end{array}$ \\
\hline $\begin{array}{c}\text { Shields, Comegys, } \\
\text { Lupton and Takei, } 2013 \\
\text { [39] }\end{array}$ & United States, Japan & $\begin{array}{l}89 \text { U.S. and } 147 \\
\text { Japanese students }\end{array}$ & $\begin{array}{l}\text { Significant differences between the countries. } \\
\text { Machiavellianism and social Darwinism are more } \\
\text { characteristic of Japanese students in most questions. } \\
\text { Japanese students in } 2011 \text { had not adopted as benign a set } \\
\text { of ethical attitudes at the same rate as their US } \\
\text { counterparts. }\end{array}$ \\
\hline $\begin{array}{l}\text { Gulova, Eryilmaz and } \\
\text { Ispirli, } 2013 \text { [40] }\end{array}$ & Turkey & 198 students & $\begin{array}{l}\text { No significant difference by gender. Business ethics } \\
\text { preferences changed positively for Machiavellianism and } \\
\text { negatively for moral objectivism or social Darwinism } \\
\text { compared to the results of [35]. }\end{array}$ \\
\hline $\begin{array}{l}\text { Phatshwane, } \\
\text { Mapharing and Basuhi, } \\
2014[41]\end{array}$ & Botswana & 195 students & $\begin{array}{l}\text { Similar results to South Africa and Turkey. Religion is } \\
\text { suggested as adding ethical values to students. }\end{array}$ \\
\hline $\begin{array}{l}\text { Knežević, Kurnoga and } \\
\text { Šimurina, } 2017 \text { [32] }\end{array}$ & Croatia & 224 students & $\begin{array}{l}\text { Cluster analysis based on new factor structure. Mainly } \\
\text { ethical, free-market supporter and financial self-interest } \\
\text { driven student groups found. }\end{array}$ \\
\hline $\begin{array}{l}\text { Clark, Tanner, Pham, } \\
\text { Lau and Nguyen, [29] }\end{array}$ & Vietnam & 282 students & $\begin{array}{l}\text { Significant differences by gender. The existence of a code of } \\
\text { ethics shows significant differences for Machiavellianism } \\
\text { and social Darwinism. }\end{array}$ \\
\hline
\end{tabular}

\section{Materials and Methods}

\subsection{Research Design}

The survey in this study used a voluntary online questionnaire for data collection. The questionnaire included statements on the perception of CSR based on the objections to it. Carroll and Shabana [42] summarized the main arguments for and against CSR. In a historical approach, the profit interest, the conflict between business and social interests, 
the diluted businesses' primary purpose, the power extension of business, and the negative impact on competitiveness are highlighted by the authors, with the remark that some still hold these in addition to the narrower interpretation of CSR. Considering the number and role of small and medium-sized enterprises (SME) in the economy, the applicability and limitations of CSR for them is an important question [43-45]. In particular, the extension of CSR to SMEs raises financial burdens. The statements were formulated as follows:

- CSR can help to achieve the goals of sustainable development.

- Another tool for companies to generate profit.

- These actions represent only greenwashing (main problems are hidden).

- $\quad$ CSR can help companies to coordinate and bring together initiations.

- $\quad$ CSR can only be successful in the case of large companies.

- CSR implementation is expensive.

The business philosophy scores were calculated by the 30 questions on the ATBEQ questionnaire as applied by $[37,46]$. The respondents were asked to mark their agreement on a 5-point scale between totally disagree (1) and totally agree (5). Table 2 assigns the questions to the philosophies based on [29]. The results on the philosophies are presented with the mean values of the related questions. The table containing the detailed analysis is presented in Appendix A.

Table 2. Calculation of business philosophy scores.

\begin{tabular}{|c|c|c|}
\hline Variable & Question Involved & Measurement \\
\hline Machiavellianism & $\begin{array}{l}\text { The only moral of business is making money. } \\
\text { A person who is doing well in business does not have to worry } \\
\text { about moral problems. } \\
\text { Business decisions involve a realistic economic attitude and not a } \\
\text { moral philosophy. } \\
\text { Moral values are irrelevant to the business world. } \\
\text { "Business ethics" is a concept for public relations only. } \\
\text { George X says of himself, "I work long, hard hours and do a good } \\
\text { job, but it seems to me that other people are progressing faster. } \\
\text { But I know my efforts will pay off in the end." Yes, George works } \\
\text { hard, but he's not realistic. } \\
\text { For every decision in business the only question I ask is, "Will it } \\
\text { be profitable?" If yes-I will act accordingly; if not, it is irrelevant } \\
\text { and a waste of time. } \\
\text { In my grocery store every week I raise the price of a certain } \\
\text { product and mark it "on sale." There is nothing wrong with } \\
\text { doing this. } \\
\text { A business person cannot afford to get hung up on ideals. } \\
\text { If you want a specific goal, you have got to take the necessary } \\
\text { means to achieve it. } \\
\text { The business world has its own rules. } \\
\text { A good business person is a successful business person. }\end{array}$ & $\begin{array}{c}\text { Mean value of } 12 \text { questions, } \\
\text { 5-point scale }\end{array}$ \\
\hline Moral objectivism & $\begin{array}{l}\text { Every business person acts according to moral principles, } \\
\text { whether he/she is aware of it or not. } \\
\text { I would rather have truth and personal responsibility than } \\
\text { unconditional love and belongingness. } \\
\text { True morality is first and foremost self-interested. } \\
\text { Self-sacrifice is immoral. } \\
\text { You can judge a person according to his work and his dedication. } \\
\text { You should not consume more than you produce. }\end{array}$ & $\begin{array}{l}\text { Mean value of } 6 \text { questions, } \\
5 \text {-point scale }\end{array}$ \\
\hline Legalism & Act according to the law, and you cannot go wrong morally. & Score of the question \\
\hline
\end{tabular}


Table 2. Cont.

\begin{tabular}{|c|c|c|}
\hline Variable & Question Involved & Measurement \\
\hline Ethical relativism & $\begin{array}{l}\text { Ethics in business is basically an adjustment between } \\
\text { expectations and the way people behave. } \\
\text { The lack of public confidence in the ethics of business people is } \\
\text { not justified. } \\
\text { The business world today is not different from what it used to be } \\
\text { in the past. There is nothing new under the sun. }\end{array}$ & $\begin{array}{c}\text { Mean value of } 3 \text { questions, } \\
\text { 5-point scale }\end{array}$ \\
\hline Social Darwinism & $\begin{array}{l}\text { Competitiveness and profitability are independent values (exist } \\
\text { on their own). } \\
\text { Conditions of a free economy will serve best the needs of society. } \\
\text { Limiting competition can only hurt society and actually violates } \\
\text { basic natural laws. } \\
\text { As a consumer when making an auto insurance claim, I try to get } \\
\text { as much as possible regardless of the extent of the damage. } \\
\text { While shopping at the supermarket, it is appropriate to switch } \\
\text { price tags or packages. } \\
\text { As an employee, I take office supplies home; it does not hurt } \\
\text { anyone. } \\
\text { I view sick days as vacation days that I deserve. } \\
\text { Employee wages should be determined according to the laws of } \\
\text { supply and demand. } \\
\text { The main interest of shareholders is maximum return on their } \\
\text { investment. }\end{array}$ & $\begin{array}{c}\text { Mean value of } 8 \text { questions, } \\
\text { 5-point scale }\end{array}$ \\
\hline
\end{tabular}

Since the data were measured on an ordinal scale, non-parametric analysis of variance (Kruskal-Wallis test) and correlations (Spearman's rho) were calculated. For a simple illustration of the results, the mean values are used in the figures.

The non-parametric Kruskal-Wallis one-way analysis of variance was applied to check the impact of different grouping factors (gender, university, level of studies, and knowledge level in CSR), but no significant differences were found in the sample. In these respects, the sample is treated as uniform.

\subsection{Research Data}

The research sample consisted of 865 responses of business students at various Hungarian higher education institutions. The data collection period ran from fall 2018 to summer 2020. The survey was managed by Evasys Survey Automation System; data analysis was supported with IBM SPSS version 25.

Overall, $32.9 \%$ of the respondents were males, and $67.1 \%$ were females. Within the the cohort, $56.4 \%$ were undertaking bachelor studies and $19.1 \%$ were undertaking master's studies. In all, $23.9 \%$ of the students were from a higher vocational level, and $0.6 \%$ were from other training backgrounds. Higher vocational training belongs to the universities in Hungary; the students learn some subjects together with bachelors. Overall, $61.2 \%$ had not learned specifically about CSR, while $26.1 \%$ demonstrated superficial knowledge and $12.7 \%$ indicated a detailed knowledge level of CSR.

\section{Results}

\subsection{Business Philosophies}

According to the mean values, Machiavellianism is the most common business philosophy among Hungarian business students, and legalism is the least common (Figure 1). Three of the five highest-rated statements belong to Machiavellianism (Figure 2). 


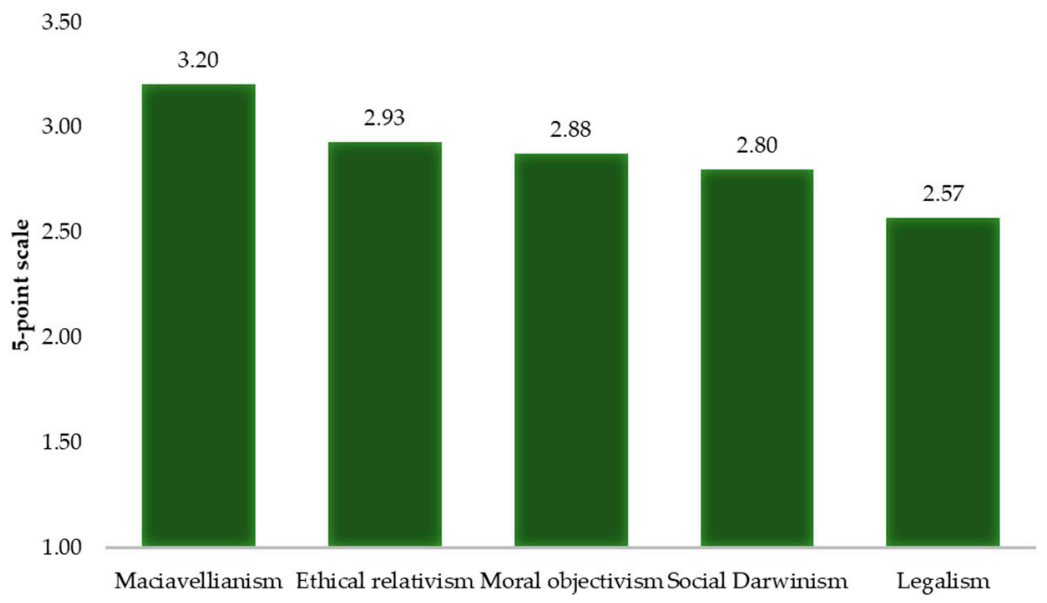

Figure 1. Business philosophies scores of Hungarian business students.

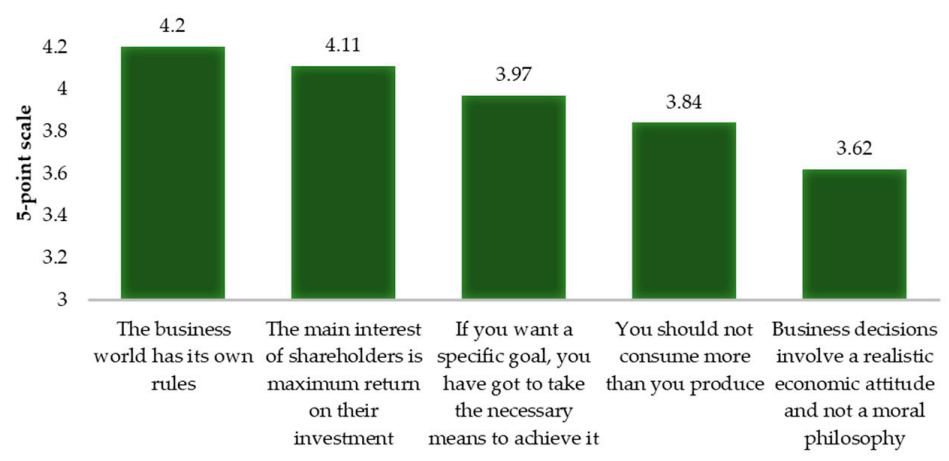

Figure 2. Top 5 rated statements of the ATBEQ questions.

The literature in the field allows an international comparison of the attitudes towards business ethics measured by the ATBEQ questions. However, the research data collection periods were not the same, assuming the high constancy of culture; the scores are comparable. The countries in Figure 3 were selected from $[35,37,47]$. The detailed scores by question are available in Appendix B. Machiavellianism is remarkably more characteristic in Hungary than in other countries, and the moral objectivism score is lower in this international comparison. Legalism is the least characteristic philosophy in most countries in this comparison (except Jamaica). The legalism score is higher in Hungary than in other European countries.

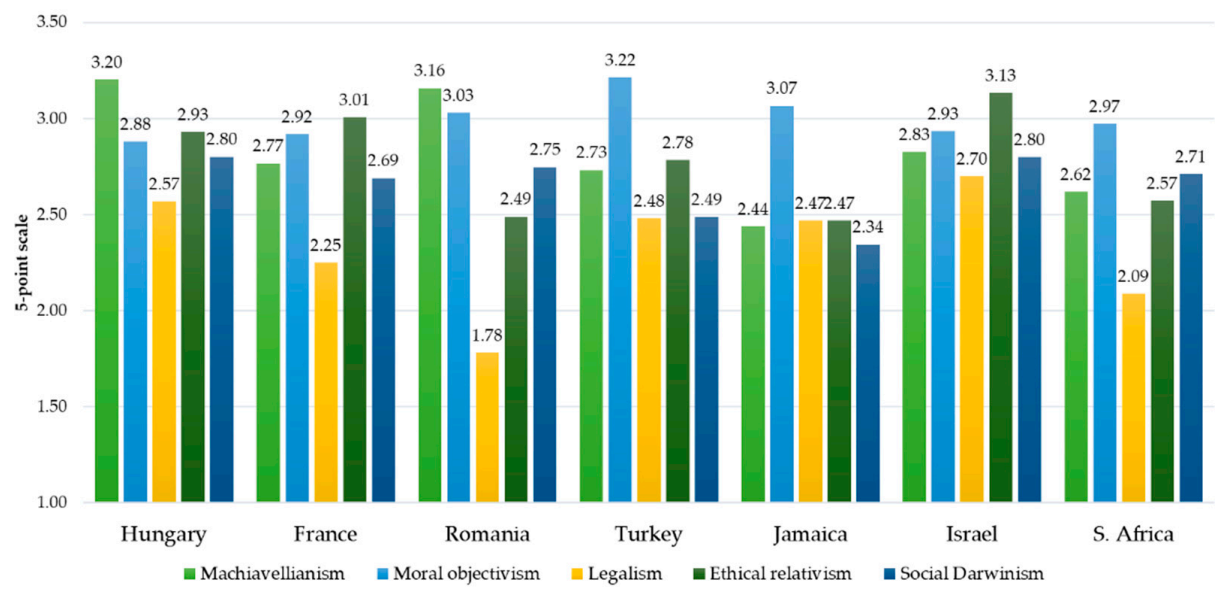

Figure 3. Business philosophy scores of selected countries $[35,37,47]$. 


\subsection{Opinions about CSR}

The survey results confirm the diverse judgments on CSR (Figure 4, Table 3). Based on the agree (4) and totally agree (5) responses, $53.6 \%$ of the respondents believe that CSR helps to achieve sustainable development goals, and 52.8\% agree that CSR can help companies to coordinate and bring together various initiatives. However, $43.7 \%$ view CSR implementation as expensive, and $40.8 \%$ believe that is just a tool for generating more profit.

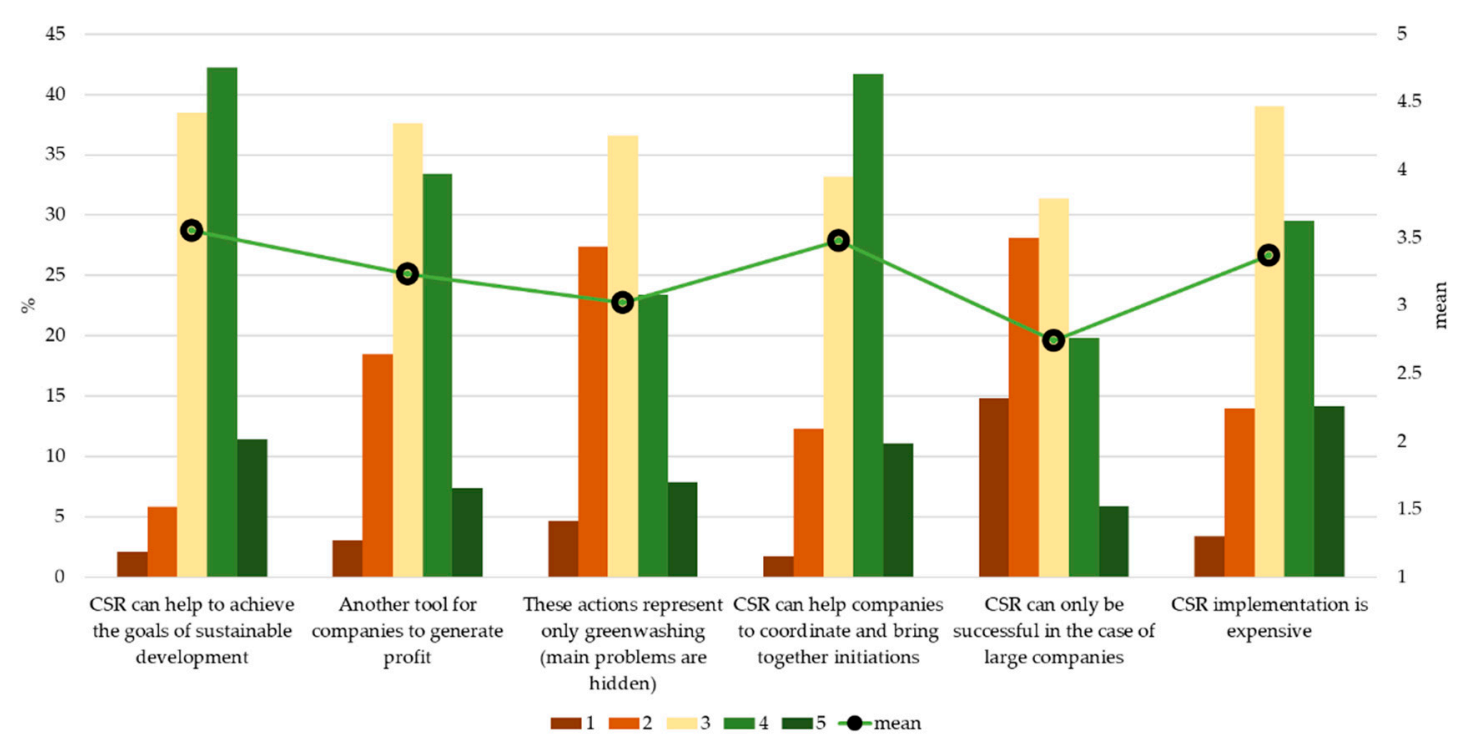

Figure 4. Distribution of responses about CSR statements and mean values.

Table 3. Distribution of the responses about CSR statements (\%).

\begin{tabular}{lccccc}
\hline Score: & $\mathbf{1}$ & $\mathbf{2}$ & $\mathbf{3}$ & $\mathbf{4}$ & $\mathbf{5}$ \\
\hline CSR can help to achieve the goals of sustainable development. & 2.1 & 5.8 & 38.5 & 42.2 & 11.4 \\
\hline Another tool for companies to generate profit. & 3.1 & 18.5 & 37.6 & 33.4 & 7.4 \\
\hline These actions represent only greenwashing (main problems are hidden). & 4.7 & 27.4 & 36.6 & 23.4 & 7.9 \\
\hline CSR can help companies to coordinate and bring together initiations. & 1.7 & 12.3 & 33.2 & 41.7 & 11.1 \\
\hline CSR can only be successful in the case of large companies. & 14.8 & 28.1 & 31.4 & 19.8 & 5.9 \\
\hline CSR implementation is expensive. & 3.4 & 14 & 39 & 29.5 & 14.2 \\
\hline
\end{tabular}

The non-parametric correlations between the responses (Table 4) are significant but weak or moderate.

\subsection{Respondent Clusters}

Although the analysis of variance did not show significant patterns by the grouping factors, the distribution of the responses in the sample suggests mixing different views on CSR. The analysis of business philosophies led to a similar conclusion. Cluster analysis was applied to explore the structure of the responses. The students' opinions about CSR were used for isolating patterns. Among the indicators of clustering, the anti-image matrix (Measures of Sampling Adequacy (MSA) $>0.5$ for each item) confirms the applicability of the method, and the scree plot (Figure 5) proposes the creation of three clusters. 
Table 4. Correlation between the responses to CSR statements (Spearman's rho, based on SPSS output).

\begin{tabular}{|c|c|c|c|c|c|c|c|}
\hline & & (1) & (2) & (3) & (4) & (5) & (6) \\
\hline $\begin{array}{c}\text { CSR can help to achieve the } \\
\text { goals of sustainable } \\
\text { development }\end{array}$ & Corr. Coef. & 1 & -0.058 & $-0.203 * *$ & $0.306^{* *}$ & $-0.082 *$ & 0.038 \\
\hline$(1)$ & Sig. & & 0.088 & 0 & 0 & 0.016 & 0.265 \\
\hline $\begin{array}{l}\text { Another tool for companies to } \\
\text { generate profit }\end{array}$ & Corr. Coef. & -0.058 & 1 & $0.271^{* *}$ & $0.074^{*}$ & $0.167^{* *}$ & $0.099 * *$ \\
\hline$(2)$ & Sig. & 0.088 & & 0 & 0.03 & 0 & 0.004 \\
\hline $\begin{array}{l}\text { These actions represent only } \\
\text { greenwashing (main problems } \\
\text { are hidden) }\end{array}$ & Corr. Coef. & $-0.203^{* *}$ & $0.271^{* *}$ & 1 & $-0.140 * *$ & $0.153^{* *}$ & $0.118^{* *}$ \\
\hline$(3)$ & Sig. & 0 & 0 & & 0 & 0 & 0 \\
\hline $\begin{array}{l}\text { CSR can help companies to } \\
\text { coordinate and bring together }\end{array}$ & Corr. Coef. & $0.306^{* *}$ & 0.074 * & $-0.140^{* *}$ & 1 & -0.033 & 0.015 \\
\hline$(4)$ & Sig. & 0 & 0.03 & 0 & & 0.335 & 0.662 \\
\hline $\begin{array}{l}\text { CSR can only be successful in } \\
\text { the case of large companies }\end{array}$ & Corr. Coef. & $-0.082 *$ & $0.167 * *$ & $0.153 * *$ & -0.033 & 1 & $0.290 * *$ \\
\hline$(5)$ & Sig. & 0.016 & 0 & 0 & 0.335 & & 0 \\
\hline $\begin{array}{l}\text { CSR implementation is } \\
\text { expensive }\end{array}$ & Corr. Coef. & 0.038 & $0.099 * *$ & $0.118 * *$ & 0.015 & $0.290 * *$ & 1 \\
\hline$(6)$ & Sig. & 0.265 & 0.004 & 0 & 0.662 & 0 & \\
\hline
\end{tabular}

*. Correlation is significant at the 0.05 level (2-tailed). ${ }^{* *}$. Correlation is significant at the 0.01 level (2-tailed).

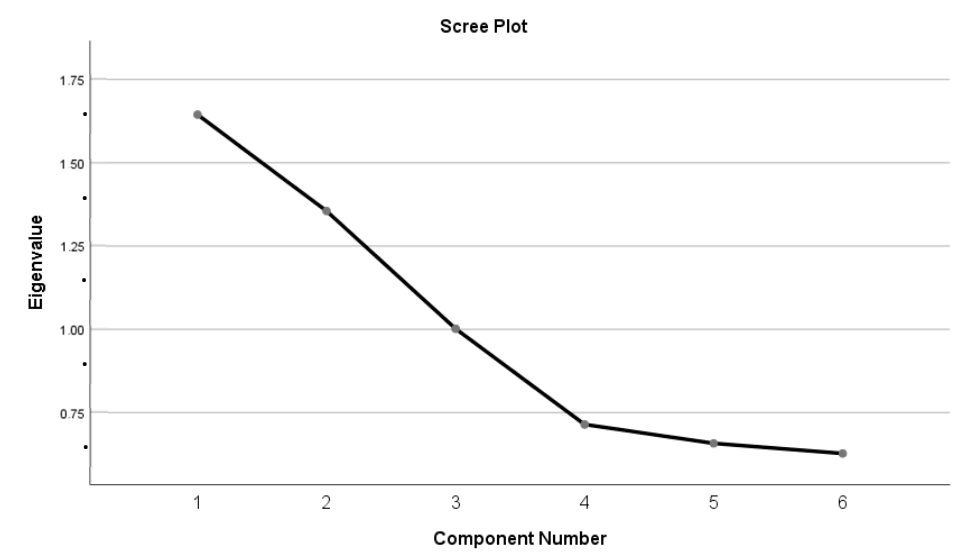

Figure 5. Scree plot to determine the cluster numbers (SPSS output).

The K-Means method $(\mathrm{K}=3)$ was used for creating the clusters. The opportunity for dimension reduction (principal component) was checked, but it was rejected because the correlation values between the responses are not high, and the total variance explained in the case of factor analysis remained low $(66.68 \%)$. It is important to note that due to uncertainty in results based on criticisms of cluster analysis [48,49], the analysis with different methods led to similar results in terms of cluster sizes and characteristics. The selection criterion for the presentation and further analysis was the most significant outcome of the analysis of variance. The results show significant differences in CSR opinions and the values of business philosophies (Table 5). 
Table 5. Non-parametric analysis of variance about CSR statements and business philosophies by clusters (Kruskal-Wallis H).

\begin{tabular}{cccc}
\hline & Kruskal-Wallis H & $\mathbf{d}_{\mathbf{f}}$ & Asymp. Sig. \\
\hline CSR can help to achieve the goals of sustainable development. & 255.506 & 2 & 0.000 \\
Another tool for companies to generate profit. & 90.494 & 2 & 0.000 \\
These actions represent only greenwashing (main problems are hidden). & 196.676 & 2 & 0.000 \\
CSR can help companies to coordinate and bring them together. & 288.803 & 2 & 0.000 \\
CSR can only be successful in the case of large companies. & 461.668 & 2 & 0.000 \\
CSR implementation is expensive. & 167.755 & 2 & 0.000 \\
Machiavellianism & 31.769 & 2 & 0.000 \\
Moral objectivism & 12.231 & 2 & 0.002 \\
Legalism & 21.547 & 2 & 0.000 \\
Ethical relativism & 12.671 & 2 & 0.002 \\
Social Darwinism & 11.460 & 2 & 0.003 \\
\hline
\end{tabular}

Based on the mean values, Figure 6 characterizes the differences in opinions by statements about CSR. Cluster $1(n=320)$ includes respondents who believe the most that CSR can help to achieve a higher level of sustainability, coordinate efforts in the field, and that CSR is available beyond large companies. The members of Cluster $2(n=273)$ believe in the usefulness of CSR, but they consider it to be of limited use. Cluster $3(n=272)$ covers respondents who believe the least in the usefulness of CSR. The question about CSR's greenwashing nature confirms this finding, showing the highest mean value in this cluster. The distribution of evaluations by clusters is summarized in Figures 7-9.

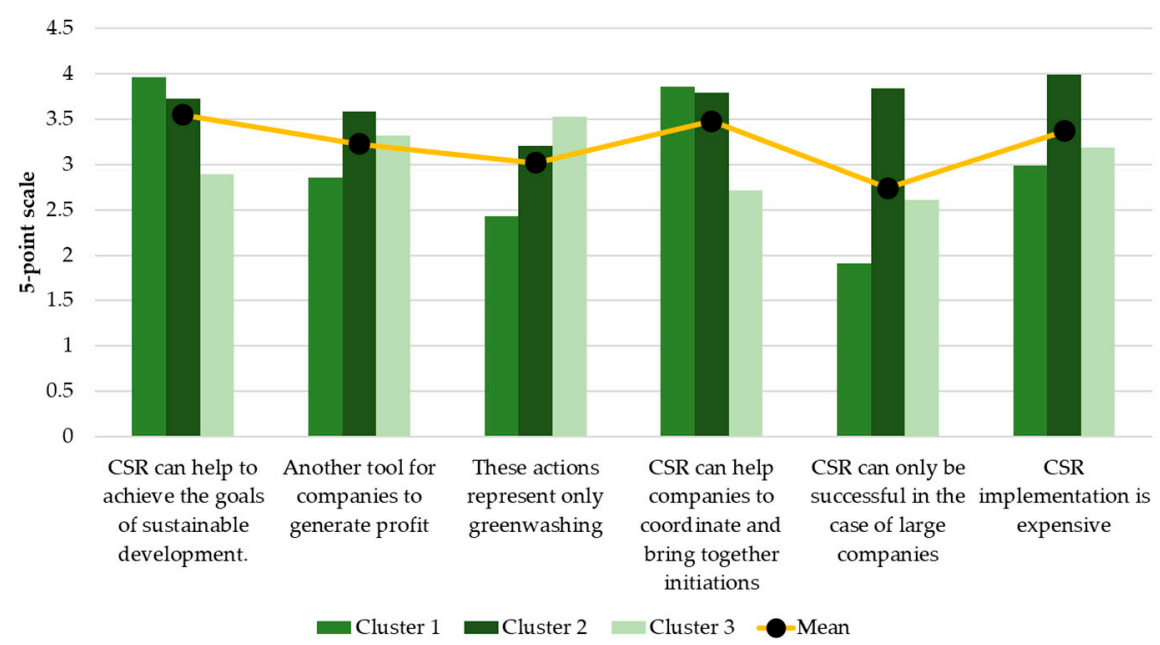

Figure 6. Mean scores of CSR statements by clusters.

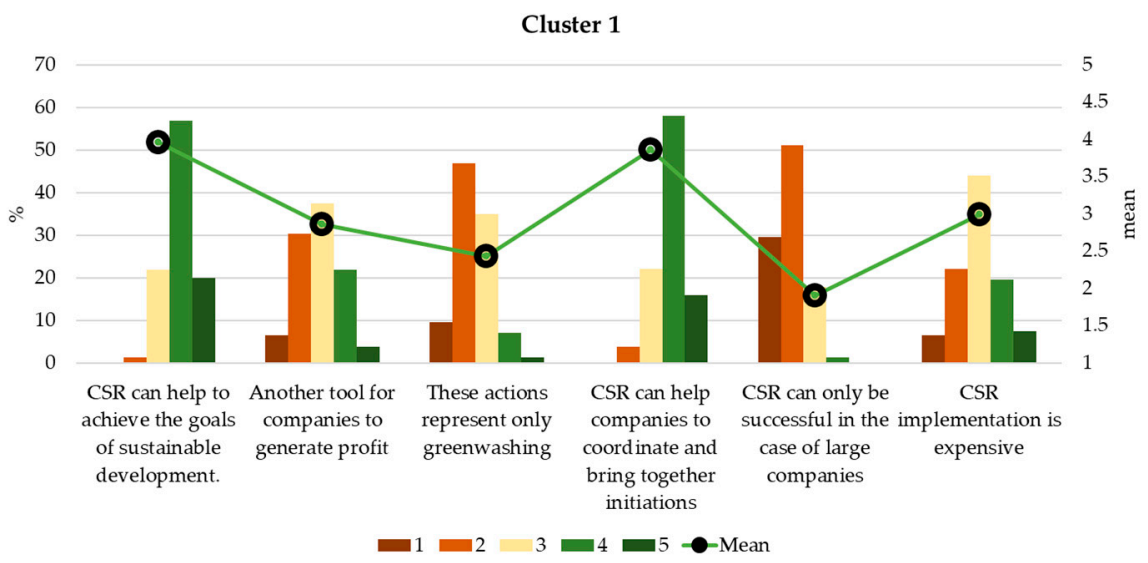

Figure 7. Distribution of responses about CSR statements, Cluster 1. 


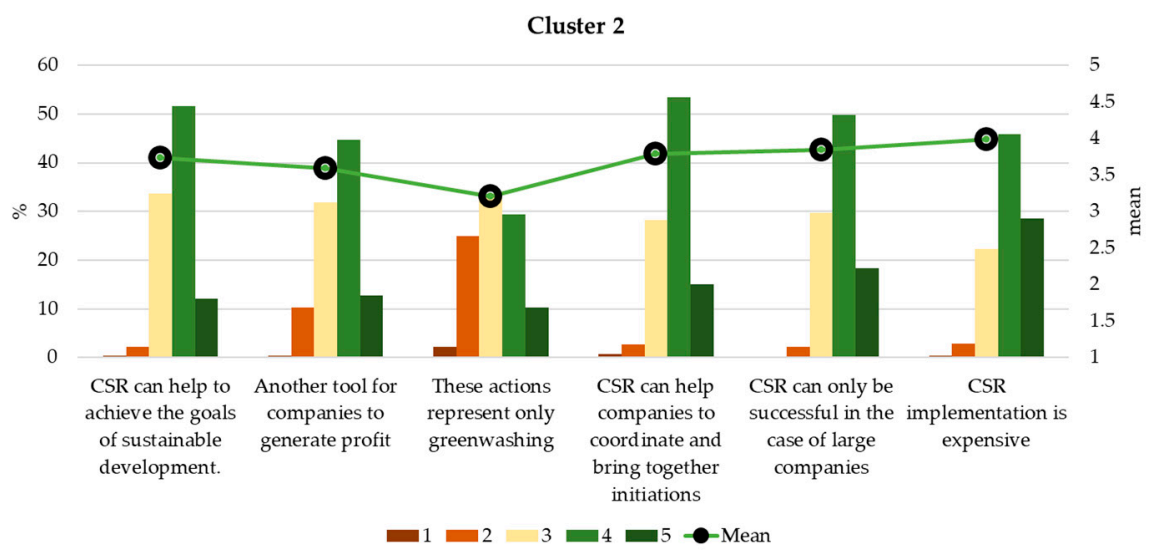

Figure 8. Distribution of responses about CSR statements, Cluster 2.

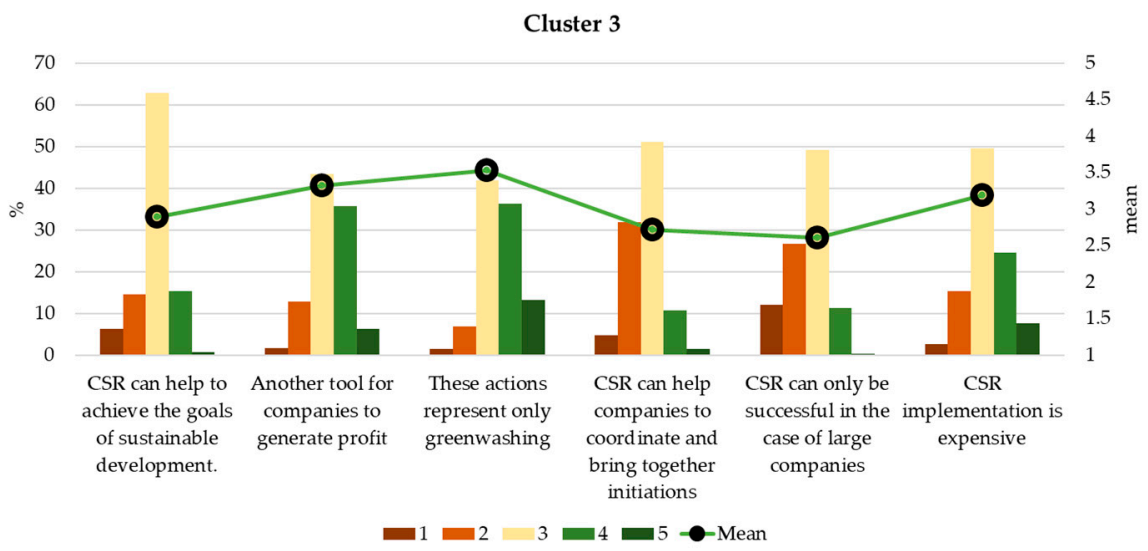

Figure 9. Distribution of responses about CSR statements, Cluster 3.

The grouping factors of the survey were checked for the clusters by crosstabulation. A significant result was found in the case of gender (Pearson chi-square $=6.222$, $\mathrm{df}=2$, sig. $=0.045$ ). Overall, $42.8 \%$ of the male and $34.1 \%$ of the female respondents belong to Cluster 1 . Within the cluster, $38.1 \%$ is the proportion of male respondents, while this ratio is $30.4 \%$ within Cluster 2 and $29.4 \%$ within Cluster 3. Other grouping factors did not show remarkable differences.

The differences in the appearance of business philosophies (mean values of the related questions) by cluster membership are summarized in Figure 10. Machiavellianism shows the highest values in all clusters, followed by ethical relativism and moral objectivism. Appendix A summarizes the detailed results by questions. Legalism shows the highest difference between the clusters. The order of the scores shows similar patterns for each cluster, but the positions of the philosophies are different:

- Cluster 2 presents the highest scores for the business philosophies in the sample.

- Machiavellianism and moral objectivism are the closest to each other in Cluster 1.

- The Machiavellianism score is lower and the legalism score is higher in Cluster 1 compared to Cluster 3.

The relative importance based on the standardized scores of the business philosophies allows a more spectacular representation of the differences (Figure 11). 


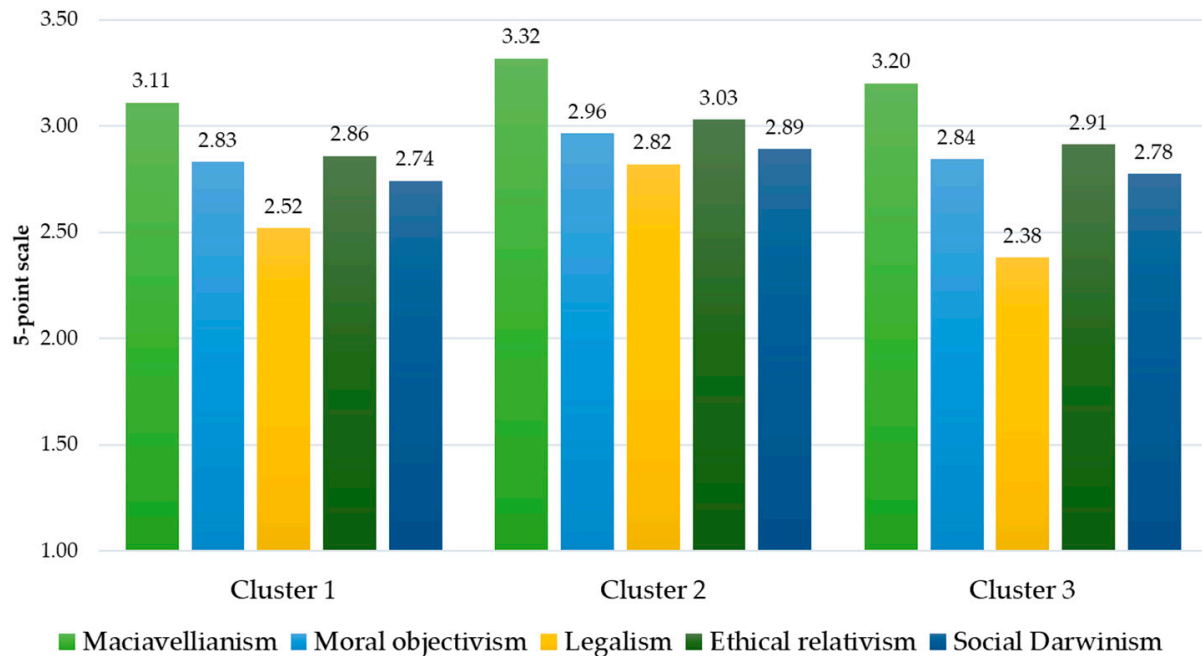

Figure 10. Mean scores of business philosophies by clusters.

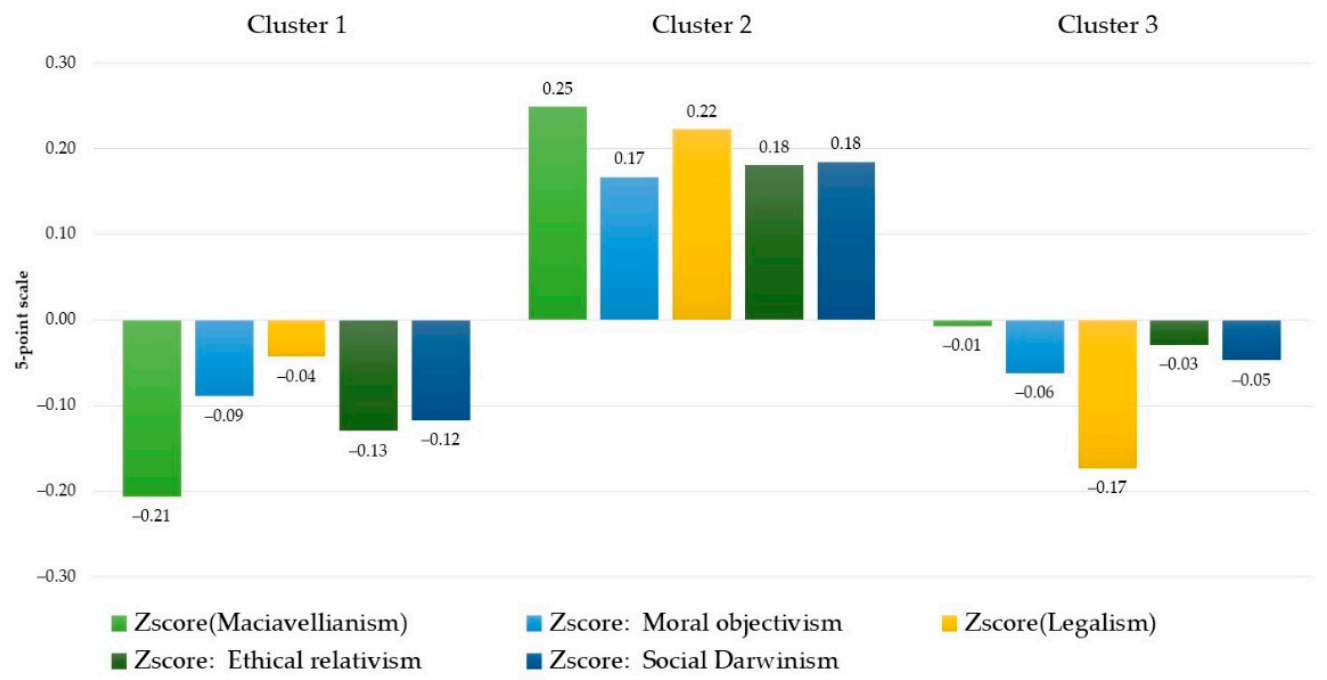

Figure 11. Standardized scores of business philosophies by clusters.

\section{Discussion}

\subsection{Opinions on CSR}

RQ1 asked what Hungarian business students interpret the role of CSR as. Overall, $61.2 \%$ of the business students in the research sample had not learned specifically about CSR. This result does not mean that corporate responsibility or stakeholder theory would also be out of the scope of the curricula of higher education institutions. The students' approach to CSR is encouraging. The fact that the proportion of students who do not believe in the contribution of CSR to a higher level of sustainability is low (Table 6) is a good starting point for the better acceptance of CSR initiatives. However, opinions are mixed as to whether it only represents greenwashing, while the main problems remain hidden. The results also show that business interest is essential, i.e., CSR is used for generating profit. A progressive consequence of the survey is that the majority of respondents do not limit CSR opportunities to large companies.

Concerning the first research question, Hungarian business students believe that CSR contributes to sustainable development and helps to coordinate initiatives in the field, but many students think that it has limitations based on company size or the implementation costs. In turn, due to the significant correlation between these questions (Spearman rho $=0.290$, sig. $=0.000$ ), based on a crosstabulation analysis, 143 respondents 
(16.5\%) scored both statements highly ( 4 or 5 on the 5 -point scale), i.e., CSR can be successful only for large companies and expensive at the same time. Table 4 summarizes the main results of the analysis (Pearson Chi-square $=199.88, \mathrm{df}=16$, sig. $=0.000$ ).

Table 6. Crosstabulation of selected statements about CSR (\% of the respondents).

\begin{tabular}{ccccc}
\hline $\begin{array}{c}\text { CSR Implementation } \\
\text { Is Expensive }\end{array}$ & Rather Disagree (1 or 2) & Uncertain (3) & Rather Agree (4 or 5) & Total \\
$\begin{array}{c}\text { CSR Can Only Be Successful } \\
\text { in the Case of large Companies }\end{array}$ & & & & \\
\hline Rather disagree (1 or 2) & 12.14 & 16.30 & 14.45 & 12.72 \\
Uncertain (3) & 3.01 & 15.72 & 16.53 & 31.45 \\
Rather agree (4 or 5) & 2.20 & 6.94 & 43.70 & 100.00 \\
Total & 17.34 & 38.96 & & \\
\hline
\end{tabular}

A remarkable result of the survey is the high proportion of uncertain responses (marked 3 on the 5-point scale). The reason for this may be due to educational shortcomings. However, this raises the future mission of education in shaping the approach to CSR.

\subsection{Business Philosophies}

RQ2 investigates the business philosophies among Hungarian business students. The role of this question in the research is to study the value system. The cultural background of the judgment on CSR must be considered on the level of personal values, companies, and nations. Pálvölgyi et al. [50] stated that CSR is a special challenge in formerly socialist countries, since the fulfillment of social goals was regarded for decades as solely the state's responsibility, and similarly, economic responsibilities were also limited. Although three decades have passed, traces of the previous system remain in these cultures. This is also indicated by comparing the Hungarian and Romain [37] scores of business philosophies; a similar pattern can be found that differs from other countries' scores (Figure 3), especially in the relative position of the scores of Machiavellianism and moral objectivism.

Machiavellianism is the main characteristic of Hungarian business students compared to other philosophies or other countries. Machiavellianism can be considered both as opportunist and realistic behavior [27]. It gives a practical approach to CSR application. According to Christie and Geis [51], in their opinion, people should believe in what they do rather than do what they believe in. Analyzing the Big Five personality trait dimensions, Czibor et al. [52] found that a high level of Machiavellianism is inversely proportional to agreeableness (friendliness) and conscientiousness. All these characteristics strengthen rationality, which is beneficial to business interests.

Moreover, the acceptance of business strategies can be increased by finding the common interest of the person and the company. The relative position of moral objectivism in the samples investigated confirms the appreciation of self-interest. In formerly socialist countries, the scores are lower than Machiavellianism scores. From a social point of view, it is important to note that the scores of social Darwinism are higher among Hungarian business students than in other countries. This suggests that utilitarian self-interest is compatible with social usefulness.

A relatively low level of legalism is present in the Hungarian sample. Since this philosophy is measured only with one statement ('Act according to the law, and you cannot go wrong morally') without further moderating questions, its reliability is questionable. Legalism can be understood as requiring that all matters of legal regulation and controversy ought to go so far as possible to be conducted in accordance with predetermined rules of considerable generality and clarity [53]. It can lead to favorable and harmful results as well. Once the low importance of rules and regulations allows constructive CSR development, it can also lead to uncontrolled initiatives. 


\subsection{Patterns}

RQ3 asks about the grouping possibilities of the Hungarian business students. The scattered distribution of the responses to the questions about CSR and the business philosophies suggests seeking subdivisions in the sample. Cluster analysis based on the CSR evaluation allowed the exposure of three respondent patterns, and analysis of variance proved its validity for assessing the business philosophies (Table 4). The mean values of the evaluations are highlighted in Figure 12. The result shows a less spectacular pattern difference according to the business philosophies, but the differences are statistically significant.

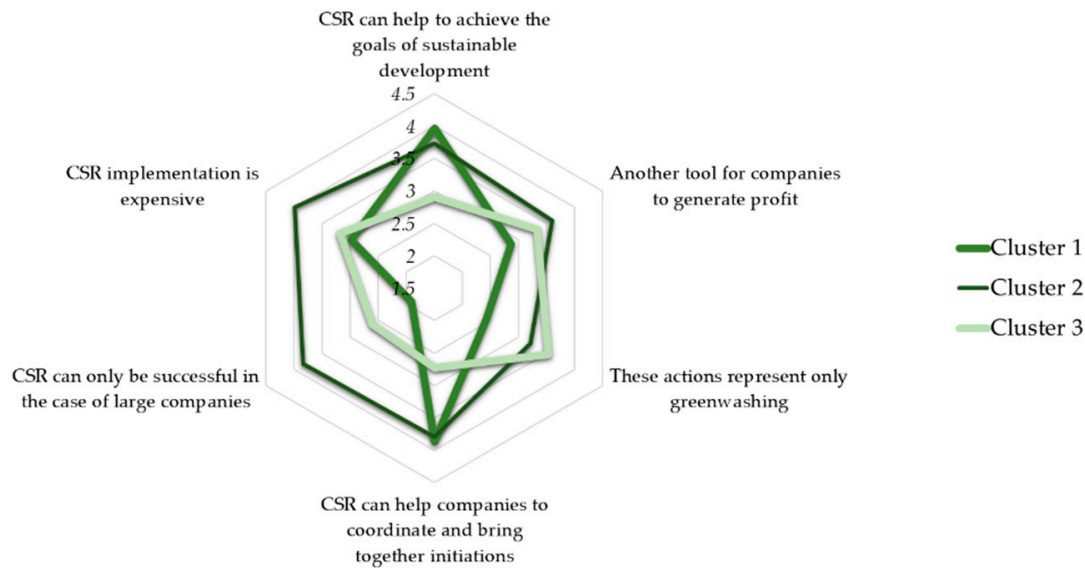

Figure 12. Comparison of the mean scores of CSR statements by cluster.

The three clusters represent remarkably different opinions on the role and opportunities of CSR.

- Cluster 1 can be assigned the name 'CSR believers'. These students believe the most in the usefulness of CSR. Moreover, they think that CSR can be successful beyond large companies at reasonable costs. They do not consider CSR as being for profit generation or greenwashing. Based on the relatively low score of Machiavellianism (Figure 11), the relegation of self-interest to the background is acceptable to members. The relatively low scores of ethical relativism and moral objectivism show higher sensitivity to diversity, including individual initiatives of companies, compared to the other clusters.

- Cluster 2 can be assigned the name 'large business-oriented'. The mean values regarding the usefulness of CSR are almost as high as in the case of 'CSR believers', but its feasibility shows a fundamentally different picture, being limited to large companies. Furthermore, business interest has a high emphasis within their opinions, including profit generation and greenwashing options. According to their business philosophies, the relative position (Figure 11) of Machiavellianism and legalism scores confirms their CSR approach. These represent the highest values among the philosophies, and self-interest is coupled with compliance, which can encourage establishing large projects with wide-ranging impacts.

- Cluster 3 contains the students who are 'skeptical' about CSR. Although these students are not those who view CSR as expensive or limited to large companies, they do not believe in its usefulness. According to the statement about the contribution of CSR to sustainable development, the highest proportion of uncertain responses is the highest within this cluster (62.9\%). Simultaneously, the profit-seeking and primarily the greenwashing nature of CSR is dominant in the opinions. The low legalism score may be the reason for their skepticism, and the standardization can be considered the tool for avoiding uncertain impacts of CSR initiatives. 


\section{Conclusions}

The study analyzed the perception of CSR, the business philosophies based on the ATBEQ questionnaire, and the relationships between these concepts among Hungarian business students. A sample of 865 respondents was available for the studies. Cluster analysis was applied for exploring patterns of thinking. There are remarkable differences found among clusters that demarcate supportive, conditional, and skeptical opinions. Conditional (large business-oriented) and supportive students are not in the minority. In addition, dedicated CSR education is not typical among the respondents.

The results show that Machiavellianism is the most characteristic business philosophy among the students. The score of this philosophy is remarkably higher compared to other countries. The highest scores are found in the large business-oriented cluster that is in line with their opinion about CSR, according to which it is useful but profit-oriented, expensive to implement, and it can only be successful in large companies.

Considering CSR as the corporate-level contribution to sustainability, understanding the perceptions of CSR among business students is an essential source for the knowledge base. Although this focus cannot cover all of the issues, business students play a crucial role as future decision-makers. Understanding and shaping their minds about CSR allows more effective company applications in the field. Consequently, the direct users of the research are higher education institutions in developing education materials, but the final beneficiaries are the companies with access to a well-trained workforce who is familiar with CSR applications. The cluster analysis results suggest targeted curriculum development, and the experience of the literature review urges that it should be based on a conceptual diversity in corporate social responsibility, even decades after its emergence.

The methodological implication of this study is that the business philosophies and the ATBEQ instrument seem to be usable for predicting the perception of CSR. Since the students' approaches to CSR correlate with their scores in the business philosophies, and as changes in culture or value systems are a slow and complicated process, the latter can be considered as enablers. A detailed examination of this conclusion is the future objective of our research, by increasing the size of the sample and building a database involving students from engineering, natural, legal, public, and social sciences. Moreover, the extension of the investigation to business practitioners would allow the conclusions to be refined. Thus, it is expected that the paper could serve as a guide for future studies, since exploring the attitudes towards CSR in more detail and identifying the influential latent variables could fill the research gap in Hungary, where research on this topic is still in its infancy. Key findings could also provide an impetus for international investigations and comparative studies.

Despite the careful preparation of the survey and the adoption of methods widely used in the related literature, some limitations of the study should be mentioned. First, the sample consists of Hungarian business students from various universities. The large research sample improves the reliability of the results, but the representativeness was not checked. Therefore, the generalization of results is limited. Second, the target group of the study consists of students whose opinions cannot fully represent all influencing factors of company decision-making. Therefore, direct company applications cannot be expected. Furthermore, a distortive effect of social expectations must be taken into account in a survey; however, the same effects appear in other studies referred to in this study.

Author Contributions: Conceptualization, L.B. and N.D.; methodology, L.B.; validation, N.D.; formal analysis, L.B. and N.D.; investigation, L.B. and N.D.; resources, L.B. and N.D.; data curation, L.B.; writing_original draft preparation, L.B.; writing—review and editing, N.D.; visualization, L.B.; supervision, N.D. All authors have read and agreed to the published version of the manuscript.

Funding: This research received no external funding.

Institutional Review Board Statement: Not applicable.

Informed Consent Statement: Informed consent was obtained from all subjects involved in the study. 
Data Availability Statement: Data available upon request by contacting first author.

Conflicts of Interest: The authors declare no conflict of interest.

\section{Appendix A}

Table A1. Descriptive statistics of the survey (mean scores of the 5-point scale and standard deviations).

\begin{tabular}{|c|c|c|c|c|c|c|c|c|}
\hline \multirow[t]{2}{*}{ Items } & \multicolumn{2}{|c|}{$\begin{array}{l}\text { Total Sample } \\
\quad(n=865)\end{array}$} & \multicolumn{2}{|c|}{$\begin{array}{l}\text { Cluster } 1 \\
(n=320)\end{array}$} & \multicolumn{2}{|c|}{$\begin{array}{l}\text { Cluster } 2 \\
(n=273)\end{array}$} & \multicolumn{2}{|c|}{$\begin{array}{l}\text { Cluster } 3 \\
(n=272)\end{array}$} \\
\hline & Mean & Std. Dev. & Mean & Std. Dev. & Mean & Std. Dev. & Mean & Std. Dev. \\
\hline \multicolumn{9}{|c|}{ CSR statements } \\
\hline $\begin{array}{l}\text { CSR can help to achieve the goals of sustainable } \\
\text { development. }\end{array}$ & 3.55 & 0.847 & 3.96 & 0.684 & 3.73 & 0.712 & 2.9 & 0.757 \\
\hline Another tool for companies to generate profit & 3.23 & 0.941 & 2.86 & 0.958 & 3.59 & 0.853 & 3.32 & 0.843 \\
\hline These actions represent only greenwashing & 3.02 & 1.006 & 2.43 & 0.813 & 3.21 & 1.001 & 3.53 & 0.863 \\
\hline $\begin{array}{l}\text { CSR can help companies to coordinate and bring } \\
\text { together initiations }\end{array}$ & 3.48 & 0.906 & 3.86 & 0.717 & 3.79 & 0.749 & 2.72 & 0.775 \\
\hline $\begin{array}{l}\text { CSR can only be successful in the case of } \\
\text { large companies }\end{array}$ & 2.74 & 1.113 & 1.91 & 0.72 & 3.84 & 0.738 & 2.61 & 0.856 \\
\hline CSR implementation is expensive & 3.37 & 1 & 2.99 & 0.992 & 3.99 & 0.813 & 3.19 & 0.882 \\
\hline \multicolumn{9}{|c|}{ ATBEQ questions } \\
\hline The only moral of business is making money. & 3.44 & 1.102 & 3.19 & 1.147 & 3.63 & 1.014 & 3.54 & 1.082 \\
\hline $\begin{array}{l}\text { A person who is doing well in business does not } \\
\text { have to worry about moral problems. }\end{array}$ & 2.79 & 1.212 & 2.46 & 1.163 & 3.11 & 1.216 & 2.88 & 1.17 \\
\hline $\begin{array}{l}\text { Every business person acts according to moral } \\
\text { principles, whether he/she is aware of it or not. }\end{array}$ & 2.43 & 1.106 & 2.39 & 1.083 & 2.57 & 1.116 & 2.32 & 1.113 \\
\hline $\begin{array}{l}\text { Act according to the law, and you cannot go } \\
\text { wrong morally. }\end{array}$ & 2.57 & 1.126 & 2.52 & 1.125 & 2.82 & 1.141 & 2.38 & 1.069 \\
\hline $\begin{array}{l}\text { Ethics in business is basically an adjustment } \\
\text { between expectations and the way } \\
\text { people behave. }\end{array}$ & 3.51 & 0.855 & 3.6 & 0.832 & 3.55 & 0.869 & 3.36 & 0.851 \\
\hline $\begin{array}{l}\text { Business decisions involve a realistic economic } \\
\text { attitude and not a moral philosophy. }\end{array}$ & 3.62 & 0.938 & 3.66 & 0.907 & 3.63 & 0.926 & 3.56 & 0.985 \\
\hline $\begin{array}{l}\text { Moral values are irrelevant to the } \\
\text { business world. }\end{array}$ & 2.99 & 1.051 & 2.79 & 1.073 & 3.13 & 1.012 & 3.1 & 1.029 \\
\hline $\begin{array}{l}\text { The lack of public confidence in the ethics of } \\
\text { business people is not justified. }\end{array}$ & 2.5 & 0.962 & 2.44 & 0.958 & 2.66 & 0.991 & 2.4 & 0.919 \\
\hline $\begin{array}{l}\text { "Business ethics" is a concept for public } \\
\text { relations only. }\end{array}$ & 2.79 & 0.952 & 2.53 & 0.933 & 2.9 & 0.882 & 2.98 & 0.975 \\
\hline $\begin{array}{l}\text { The business world today is not different from } \\
\text { what it used to be in the past. There is nothing } \\
\text { new under the sun. }\end{array}$ & 2.78 & 1.179 & 2.54 & 1.125 & 2.87 & 1.195 & 2.99 & 1.176 \\
\hline $\begin{array}{l}\text { Competitiveness and profitability are } \\
\text { independent values (exist on their own). }\end{array}$ & 2.68 & 1.087 & 2.61 & 1.125 & 2.78 & 1.076 & 2.66 & 1.047 \\
\hline $\begin{array}{l}\text { Conditions of a free economy will serve best the } \\
\text { needs of society. Limiting competition can only } \\
\text { hurt society and actually violates basic } \\
\text { natural laws. }\end{array}$ & 3.09 & 1.035 & 3.09 & 1.078 & 3.18 & 1.007 & 3.02 & 1.011 \\
\hline
\end{tabular}


Table A1. Cont.

\begin{tabular}{|c|c|c|c|c|c|c|c|c|}
\hline \multirow[t]{2}{*}{ Items } & \multicolumn{2}{|c|}{$\begin{array}{l}\text { Total Sample } \\
\quad(n=865)\end{array}$} & \multicolumn{2}{|c|}{$\begin{array}{l}\text { Cluster } 1 \\
(n=320)\end{array}$} & \multicolumn{2}{|c|}{$\begin{array}{l}\text { Cluster } 2 \\
(n=273)\end{array}$} & \multicolumn{2}{|c|}{$\begin{array}{l}\text { Cluster } 3 \\
(n=272)\end{array}$} \\
\hline & Mean & Std. Dev. & Mean & Std. Dev. & Mean & Std. Dev. & Mean & Std. Dev. \\
\hline $\begin{array}{l}\text { As a consumer when making an auto insurance } \\
\text { claim, I try to get as much as possible regardless } \\
\text { of the extent of the damage. }\end{array}$ & 3.32 & 1.094 & 3.34 & 1.117 & 3.34 & 1.07 & 3.26 & 1.092 \\
\hline $\begin{array}{l}\text { While shopping at the supermarket, it is } \\
\text { appropriate to switch price tags or packages. }\end{array}$ & 1.76 & 1.062 & 1.6 & 1.003 & 1.87 & 1.127 & 1.84 & 1.042 \\
\hline $\begin{array}{l}\text { As an employee, I take office supplies home; it } \\
\text { does not hurt anyone. }\end{array}$ & 2.02 & 1.146 & 1.89 & 1.118 & 2.14 & 1.194 & 2.04 & 1.118 \\
\hline I view sick days as vacation days that I deserve. & 2.32 & 1.285 & 2.16 & 1.244 & 2.49 & 1.331 & 2.33 & 1.269 \\
\hline $\begin{array}{l}\text { Employee wages should be determined } \\
\text { according to the laws of supply and demand. }\end{array}$ & 3.11 & 1.131 & 3.11 & 1.184 & 3.25 & 1.1 & 2.96 & 1.083 \\
\hline $\begin{array}{l}\text { The main interest of shareholders is maximum } \\
\text { return on their investment. }\end{array}$ & 4.11 & 0.946 & 4.13 & 0.998 & 4.09 & 0.876 & 4.09 & 0.954 \\
\hline $\begin{array}{l}\text { George X says of himself, "I work long, hard } \\
\text { hours and do a good job, but it seems to me that } \\
\text { other people are progressing faster. But I know } \\
\text { my efforts will pay off in the end." Yes, George } \\
\text { works hard, but he's not realistic. }\end{array}$ & 3.09 & 1.071 & 3.03 & 1.142 & 3.21 & 1.023 & 3.07 & 1.025 \\
\hline $\begin{array}{l}\text { For every decision in business the only question } \\
\text { I ask is, "Will it be profitable?" If yes-I will act } \\
\text { accordingly; if not, it is irrelevant and a waste of } \\
\text { time. }\end{array}$ & 3.39 & 1.134 & 3.33 & 1.212 & 3.48 & 1.061 & 3.36 & 1.108 \\
\hline $\begin{array}{l}\text { In my grocery store every week I raise the price } \\
\text { of a certain product and mark it "on sale." There } \\
\text { is nothing wrong with doing this. }\end{array}$ & 1.73 & 1.004 & 1.54 & 0.902 & 1.84 & 1 & 1.84 & 1.087 \\
\hline $\begin{array}{l}\text { A business person cannot afford to get hung up } \\
\text { on ideals. }\end{array}$ & 3.09 & 1.058 & 3.02 & 1.11 & 3.19 & 1.042 & 3.09 & 1.007 \\
\hline $\begin{array}{l}\text { If you want a specific goal, you have got to take } \\
\text { the necessary means to achieve it. }\end{array}$ & 3.97 & 0.991 & 4.05 & 0.917 & 4.02 & 0.996 & 3.82 & 1.056 \\
\hline The business world has its own rules. & 4.2 & 0.846 & 4.31 & 0.756 & 4.29 & 0.795 & 4 & 0.955 \\
\hline $\begin{array}{l}\text { A good business person is a successful } \\
\text { business person. }\end{array}$ & 3.34 & 1.062 & 3.44 & 1.027 & 3.4 & 1.067 & 3.18 & 1.082 \\
\hline $\begin{array}{l}\text { I would rather have truth and personal } \\
\text { responsibility than unconditional love and } \\
\text { belongingness. }\end{array}$ & 3.25 & 1.034 & 3.21 & 1.026 & 3.26 & 1.036 & 3.27 & 1.045 \\
\hline True morality is first and foremost self-interested. & 2.91 & 1.148 & 2.82 & 1.235 & 3.01 & 1.101 & 2.9 & 1.08 \\
\hline Self-sacrifice is immoral. & 2.08 & 0.984 & 1.96 & 0.946 & 2.22 & 1.047 & 2.08 & 0.948 \\
\hline $\begin{array}{l}\text { You can judge a person according to his work } \\
\text { and his dedication. }\end{array}$ & 2.77 & 1.16 & 2.73 & 1.2 & 2.83 & 1.141 & 2.75 & 1.132 \\
\hline $\begin{array}{l}\text { You should not consume more than } \\
\text { you produce. }\end{array}$ & 3.84 & 1.089 & 3.87 & 1.07 & 3.9 & 1.09 & 3.74 & 1.107 \\
\hline \multicolumn{9}{|c|}{ Mean scores of business philosophies } \\
\hline Machiavellianism & 3.20 & 0.46 & 3.11 & 0.46 & 3.32 & 0.42 & 3.20 & 0.47 \\
\hline Moral objectivism & 2.88 & 0.52 & 2.83 & 0.53 & 2.96 & 0.55 & 2.84 & 0.48 \\
\hline Legalism & 2.57 & 1.13 & 2.52 & 1.13 & 2.82 & 1.14 & 2.38 & 1.07 \\
\hline Ethical relativism & 2.93 & 0.55 & 2.86 & 0.50 & 3.03 & 0.59 & 2.91 & 0.54 \\
\hline Social Darwinism & 2.80 & 0.49 & 2.74 & 0.48 & 2.89 & 0.52 & 2.78 & 0.48 \\
\hline
\end{tabular}




\section{Appendix B}

Table A2. International comparison of ATBEQ surveys (based on $[35,37,47]$ ).

\begin{tabular}{|c|c|c|c|c|c|c|c|}
\hline Items & Hungary & France & Romania & Turkey & Jamaica & Israel & S. Africa \\
\hline The only moral of business is making money. & 3.44 & 2.9 & 3.53 & 2.15 & 2.2 & 2.8 & 2.31 \\
\hline $\begin{array}{l}\text { A person who is doing well in business does not } \\
\text { have to worry about moral problems. }\end{array}$ & 2.79 & 1.75 & 3.42 & 2.05 & 1.37 & 1.8 & 1.68 \\
\hline $\begin{array}{l}\text { Every business person acts according to moral } \\
\text { principles, whether he/she is aware of it or not. }\end{array}$ & 2.43 & 3.33 & 2.95 & 2.82 & 2.86 & 2.5 & 2.97 \\
\hline $\begin{array}{l}\text { Act according to the law, and you cannot go } \\
\text { wrong morally. }\end{array}$ & 2.57 & 2.25 & 1.78 & 2.48 & 2.47 & 2.7 & 2.09 \\
\hline $\begin{array}{l}\text { Ethics in business is basically an adjustment } \\
\text { between expectations and the way people behave. }\end{array}$ & 3.51 & 3.24 & 2.32 & 3.41 & 3.02 & 3.2 & 3.01 \\
\hline $\begin{array}{l}\text { Business decisions involve a realistic economic } \\
\text { attitude and not a moral philosophy. }\end{array}$ & 3.62 & 3.07 & 3.82 & 2.65 & 2.86 & 3.6 & 3.01 \\
\hline Moral values are irrelevant to the business world. & 2.99 & 2.17 & 2.52 & 2.12 & 1.68 & 2.4 & 1.76 \\
\hline $\begin{array}{l}\text { The lack of public confidence in the ethics of } \\
\text { business people is not justified. }\end{array}$ & 2.5 & 3.23 & 2.9 & 2.97 & 2.48 & 2.9 & 2.73 \\
\hline $\begin{array}{l}\text { "Business ethics" is a concept for public } \\
\text { relations only. }\end{array}$ & 2.79 & 2.55 & 1.58 & 1.75 & 1.75 & 2.8 & 1.99 \\
\hline $\begin{array}{l}\text { The business world today is not different from } \\
\text { what it used to be in the past. There is nothing } \\
\text { new under the sun. }\end{array}$ & 2.78 & 2.55 & 2.25 & 1.97 & 1.91 & 3.3 & 1.98 \\
\hline $\begin{array}{l}\text { Competitiveness and profitability are independent } \\
\text { values (exist on their own). }\end{array}$ & 2.68 & 2.87 & 2.03 & 2.2 & 2.27 & 3.4 & 2.26 \\
\hline $\begin{array}{l}\text { Conditions of a free economy will serve best the } \\
\text { needs of society. Limiting competition can only } \\
\text { hurt society and actually violates basic } \\
\text { natural laws. }\end{array}$ & 3.09 & 3.17 & 3.72 & 3.45 & 3.33 & 3.6 & 3.6 \\
\hline $\begin{array}{l}\text { As a consumer when making an auto insurance } \\
\text { claim, I try to get as much as possible regardless of } \\
\text { the extent of the damage. }\end{array}$ & 3.32 & 2.83 & 2.58 & 2.71 & 2.36 & 2.9 & 3.31 \\
\hline $\begin{array}{l}\text { While shopping at the supermarket, it is } \\
\text { appropriate to switch price tags or packages. }\end{array}$ & 1.76 & 1.68 & 1.36 & 1.37 & 1.12 & 1.6 & 1.6 \\
\hline $\begin{array}{l}\text { As an employee, I take office supplies home; it } \\
\text { does not hurt anyone. }\end{array}$ & 2.02 & 2.81 & 2.16 & 1.57 & 1.5 & 1.5 & 2.15 \\
\hline I view sick days as vacation days that I deserve. & 2.32 & 1.59 & 2.73 & 1.91 & 1.66 & 2.5 & 2.12 \\
\hline $\begin{array}{l}\text { Employee wages should be determined according } \\
\text { to the laws of supply and demand. }\end{array}$ & 3.11 & 2.54 & 3.14 & 2.9 & 2.29 & 2.9 & 2.7 \\
\hline $\begin{array}{l}\text { The main interest of shareholders is maximum } \\
\text { return on their investment. }\end{array}$ & 4.11 & 4.03 & 4.26 & 3.8 & 4.22 & 4 & 3.95 \\
\hline $\begin{array}{l}\text { George X says of himself, "I work long, hard hours } \\
\text { and do a good job, but it seems to me that other } \\
\text { people are progressing faster. But I know my } \\
\text { efforts will pay off in the end." Yes, George works } \\
\text { hard, but he's not realistic. }\end{array}$ & 3.09 & 3.07 & 3.26 & 2.99 & 2.96 & 3 & 3.17 \\
\hline $\begin{array}{l}\text { For every decision in business the only question I } \\
\text { ask is, "Will it be profitable?" If yes-I will act } \\
\text { accordingly; if not, it is irrelevant and a waste } \\
\text { of time. }\end{array}$ & 3.39 & 3.06 & 3.52 & 2.71 & 2.7 & 3.4 & 2.55 \\
\hline
\end{tabular}


Table A2. Cont.

\begin{tabular}{|c|c|c|c|c|c|c|c|}
\hline Items & Hungary & France & Romania & Turkey & Jamaica & Israel & S. Africa \\
\hline $\begin{array}{l}\text { In my grocery store every week I raise the price of } \\
\text { a certain product and mark it "on sale." There is } \\
\text { nothing wrong with doing this. }\end{array}$ & 1.73 & 1.57 & 1.8 & 1.54 & 1.27 & 1.8 & 2.07 \\
\hline $\begin{array}{l}\text { A business person cannot afford to get hung up } \\
\text { on ideals. }\end{array}$ & 3.09 & 2.32 & 2.68 & 3.64 & 1.94 & 2.5 & 2.48 \\
\hline $\begin{array}{l}\text { If you want a specific goal, you have got to take } \\
\text { the necessary means to achieve it. }\end{array}$ & 3.97 & 3.91 & 3.87 & 3.98 & 4.18 & 2.7 & 3.85 \\
\hline The business world has its own rules. & 4.2 & 3.61 & 3.89 & 4.11 & 3.36 & 3.6 & 3.44 \\
\hline $\begin{array}{l}\text { A good business person is a successful } \\
\text { business person. }\end{array}$ & 3.34 & 3.22 & 4.01 & 3.1 & 2.99 & 3.5 & 3.12 \\
\hline $\begin{array}{l}\text { I would rather have truth and personal } \\
\text { responsibility than unconditional love and } \\
\text { belongingness. }\end{array}$ & 3.25 & 2.54 & 3 & 3.15 & 3.06 & 3.3 & 3.24 \\
\hline True morality is first and foremost self-interested. & 2.91 & 2.59 & 2.69 & 4.12 & 3.04 & 2.5 & 2.99 \\
\hline Self-sacrifice is immoral. & 2.08 & 2.65 & 2.59 & 1.88 & 2.2 & 2.5 & 2.36 \\
\hline $\begin{array}{l}\text { You can judge a person according to his work and } \\
\text { his dedication. }\end{array}$ & 2.77 & 3.18 & 3.53 & 3.44 & 3.62 & 3.6 & 3.29 \\
\hline You should not consume more than you produce. & 3.84 & 3.22 & 3.42 & 3.88 & 3.62 & 3.2 & 2.98 \\
\hline Mean values: & Hungary & France & Romania & Turkey & Jamaica & Israel & S. Africa \\
\hline Machiavellianism & 3.20 & 2.77 & 3.16 & 2.73 & 2.44 & 2.83 & 2.62 \\
\hline Moral objectivism & 2.88 & 2.92 & 3.03 & 3.22 & 3.07 & 2.93 & 2.97 \\
\hline Legalism & 2.57 & 2.25 & 1.78 & 2.48 & 2.47 & 2.70 & 2.09 \\
\hline Ethical relativism & 2.93 & 3.01 & 2.49 & 2.78 & 2.47 & 3.13 & 2.57 \\
\hline Social Darwinism & 2.80 & 2.69 & 2.75 & 2.49 & 2.34 & 2.80 & 2.71 \\
\hline
\end{tabular}

\section{References}

1. Moore, J.E.; Mascarenhas, A.; Bain, J.; Straus, S.E. Developing a comprehensive definition of sustainability. Implement. Sci. 2017, 12, 1-8. [CrossRef] [PubMed]

2. United Nations. Transforming Our World: The 2030 Agenda for Sustainable Development. 2015. Available online: https: / / sustainabledevelopment.un.org/ (accessed on 5 August 2021).

3. Salvia, A.L.; Filho, W.L.; Brandli, L.L.; Griebeler, J.S. Assessing research trends related to Sustainable Development Goals: Local and global issues. J. Clean. Prod. 2019, 208, 841-849. [CrossRef]

4. Szennay, Á.; Szigeti, C.; Kovács, N.; Szabó, D.R. Through the Blurry Looking Glass-SDGs in the GRI Reports. Resources 2019, 8, 101. [CrossRef]

5. Szegedi, K.; Fülöp, G.Y.; Bereczk, Á. Fogalmi meghatározások, modellek és példák a vállalati társadalmi felelősség és a tár-sadalmi innováció hazai és nemzetközi irodalmából Észak-Magy. Strat. Füzetek 2015, 12, 122-128.

6. Braun, R. A vállalatok politikája: Vállalati társadalmi felelősségvállalás, vállalati közösségek és a vállalati stratégia jövője. Vezetéstudomány 2013, 44, 18-28. [CrossRef]

7. Friedman, M. The Social Responsibility of Business is to Increase its Profits. New York Times Magazine, 13 September 1970; pp. 122-124.

8. $\quad$ Rappaport, A. Creating Shareholder Value: A Guide for Managers and Investors; Free Press: New York, NY, USA, 1997.

9. Steurer, R.; Langer, M.E.; Konrad, A.; Martinuzzi, A. Corporations, Stakeholders and Sustainable Development I: A Theoretical Exploration of Business-Society Relations. J. Bus. Ethics 2005, 61, 263-281. [CrossRef]

10. Bowen, H.R. Social Responsibilities of the Businessman; Harper: New York, NY, USA, 1953.

11. International Organization for Standardization2010. Guidance on Social Responsibility (ISO Standard No. 26000). Available online: https: / / www.iso.org/standard/42546.html (accessed on 1 June 2021).

12. Graafland, J.; Mazereeuw-van der Duijn Schouten, C. Motives for Corporate Social Responsibility. De Econ. 2012, 160, 377-396. [CrossRef]

13. Lewis, S. Reputation and corporate responsibility. J. Commun. Manag. 2003, 7, 356-366. [CrossRef] 
14. Habek, P. CSR Reporting Practices in Visegrad Group Countries and the Quality of Disclosure. Sustainability 2017, 9, 2322. [CrossRef]

15. Bhatia, A.; Makkar, B. Extent and drivers of CSR disclosure: Evidence from Russia. Transnatl. Corp. Rev. 2019, 11, 190-207. [CrossRef]

16. Tulcanaza-Prieto, A.; Shin, H.; Lee, Y.; Lee, C.W. Relationship among CSR Initiatives and Financial and Non-Financial Corporate Performance in the Ecuadorian Banking Environment. Sustainability 2020, 12, 1621. [CrossRef]

17. Dahlsrud, A. How corporate social responsibility is defined: An analysis of 37 definitions. Corp. Soc. Responsib. Environ. Manag. 2008, 15, 1-13. [CrossRef]

18. Fassin, Y.; Van Rossem, A.; Buelens, M. Small-Business Owner-Managers' Perceptions of Business Ethics and CSR-Related Concepts. J. Bus. Ethics 2011, 98, 425-453. [CrossRef]

19. De Bakker, F.G.; Groenewegen, P.; den Hond, F. A Bibliometric Analysis of 30 Years of Research on Corporate Social Responsibility and Corporate Social Performance. Bus. Soc. 2005, 44, 283-317. [CrossRef]

20. Carroll, A.B. A History of Corporate Social Responsibility: Concepts and Practices. In The Oxford Handbook of Corporate Social Responsibility; Crane, A., Matten, D., McWilliams, A., Moon, J., Siegel, D.S., Eds.; Oxford University Press: Oxford, UK, 2009.

21. Commission of the European Communities. Promoting a European Framework for Corporate Social Responsibility; COM (2001) 366; European Commission: Brussels, Belgium, 2001.

22. European Commission. Communication from the Commission to the European Parliament. The Council. The European Eco-nomic and Social Committee and the Committee of the Regions. A Renewed EU strategy 2011-2014 for Corporate Social Responsibility; COM(2011) 681; European Commission: Brussels, Belgium, 2011. Available online: https:/ / eur-lex.europa.eu/LexUriServ/LexUriServ.do? uri=COM:2011:0681:FIN:EN:PDF (accessed on 1 June 2021).

23. McAleer, S. Friedman's Stockholder Theory of Corporate Moral Responsibility. Teach. Bus. Ethics 2003, 7, 437-451. [CrossRef]

24. Joyner, B.E.; Payne, D. Evolution and Implementation: A Study of Values, Business Ethics and Corporate Social Responsibility. J. Bus. Ethics 2002, 41, 297-311. [CrossRef]

25. Carroll, A.B. The pyramid of corporate social responsibility: Toward the moral management of organizational stakeholders. Bus. Horiz. 1991, 34, 39-48. [CrossRef]

26. Stevens, E. Business Ethics; Paulist Press: New York/Ramsey, NY, USA, 1979.

27. Miesing, P.; Preble, J.F. A comparison of five business philosophies. J. Bus. Ethics 1985, 4, 465-476. [CrossRef]

28. Neumann, Y.; Reichel, A. The Development of Attitudes Toward Business Ethics Questionnaire (ATBEQ): Concepts, Dimensions, and Relations to Work Values; Working Paper; Department of Industrial Engineering and Management, Ben Gurion University of the Negev: Be'er Sheva, Israel, 1987.

29. Clark, D.; Tanner, T.; Pham, L.N.; Lau, W.K.; Nguyen, L.D. Attitudes toward business ethics: Empirical investigation on different moral philosophies among business students in Vietnam. Int. J. Bus. Gov. Ethics 2020, 14, 123-142. [CrossRef]

30. Davis, M.A.; Andersen, M.G.; Curtis, M.B. Measuring Ethical Ideology in Business Ethics: A Critical Analysis of the Ethics Position Questionnaire. J. Bus. Ethics 2001, 32, 35-53. [CrossRef]

31. Preble, J.F.; Reichel, A. Attitudes Towards Business Ethics of Future Managers in the US and Israel. J. Bus. Ethics 1988, 7, 941-949.

32. Knežević, B.; Kurnoga, N.; Šimurina, N. Multivariate analysis of attitudes on financial and other aspects of business ethics of future managers. Croat. Oper. Res. Rev. 2017, 8, 93-105. [CrossRef]

33. Small, M.W. Attitudes towards business ethics held by Western Australian students: A comparative study. J. Bus. Ethics 1992, 11, 745-752. [CrossRef]

34. Moore, R.S.; Radloff, S.E. Attitudes towards business ethics held by South African students. J. Bus. Ethics 1996, 15, 863-869. [CrossRef]

35. Sims, R.L.; Gegez, A.E. Attitudes towards Business Ethics: A Five Nation Comparative Study. J. Bus. Ethics 2004, 50, 253-265. [CrossRef]

36. Kum-Lung, C.; Teck-Chai, L. Attitude towards Business Ethics: Examining the Influence of Religiosity, Gender and Education Levels. Int. J. Mark. Stud. 2010, 2, 226-232. [CrossRef]

37. Bageac, D.; Furrer, O.; Reynaud, E. Management Students' Attitudes Toward Business Ethics: A Comparison Between France and Romania. J. Bus. Ethics 2011, 98, 391-406. [CrossRef]

38. Price, G.; Van Der Walt, A.J. Changes in Attitudes Towards Business Ethics Held by Former South African Business Management Students. J. Bus. Ethics 2013, 113, 429-440. [CrossRef]

39. Shields, R.; Comegys, C.; Lupton, R.; Takei, H. Undergraduate Attitudes Toward Business Ethics: A Cross-Cultural Comparison. J. Stud. Educ. 2013, 3, 72. [CrossRef]

40. Gulova, A.; Eryilmaz, I.; Ispirli, D. Attitudes towards business ethics: An empirical study on Turkish senior business students. Int. Proc. Econ. Dev. Res. 2013, 65, 42-47. [CrossRef]

41. Phatshwane, P.M.D.; Mapharing, M.; Basuhi, E.J. Attitudes towards Business Ethics Held by Accountancy and Finance Students in the University of Botswana. Int. J. Bus. Manag. 2014, 9, 17-29. [CrossRef]

42. Carroll, A.B.; Shabana, K.M. The Business Case for Corporate Social Responsibility: A Review of Concepts, Research and Practice. Int. J. Manag. Rev. 2010, 12, 85-105. [CrossRef]

43. Jenkins, H. A Critique of Conventional CSR Theory: An SME Perspective. J. Gen. Manag. 2004, 29, 37-57. [CrossRef]

44. Santos, M.J. CSR in SMEs: Strategies, practices, motivations and obstacles. Soc. Responsib. J. 2011, 7, 490-508. [CrossRef] 
45. Kechiche, A.; Soparnot, R. CSR within SMEs: Literature Review. Int. Bus. Res. 2012, 5, 97-104. [CrossRef]

46. Pham, L.N.; Nguyen, L.D.; Favia, M.J. Business students' attitudes toward business ethics: An empirical investigation in Vietnam. J. Asia Bus. Stud. 2015, 9, 289-305. [CrossRef]

47. Sims, R.L. Comparing ethical attitudes across cultures. Cross Cult. Manag. Int. J. 2006, 13, 101-113. [CrossRef]

48. Pallant, J. SPSS Survival Manual: A Step by Step Guide to Data Analysis Using IBM SPSS, 7th ed.; Open University Press: London, UK, 2020.

49. Sajtos, L.; Mitev, A. SPSS Kutatási és Adatelemzési Kézikönyv; Alinea: Budapest, Hungary, 2007.

50. Pálvölgyi, T.; Nagypál, N.C.; Szlávik, J.; Csáfor, H.; Csete, M. Striking Oil? CSR and the EU Integration Processes: The Example of Hungary. In Corporate Social Responsibility in Europe. Rhetoric and Realities; Barth, R., Wolff, E., Eds.; Edward Elgar: Cheltenham, UK; Northampton, UK, 2009; pp. 269-288.

51. Christie, R.; Geis, F. Studies in Machiavellianism; Academic Press: New York, NY, USA, 1970.

52. Czibor, A.; Vincze, O.; Bereczkei, T. Feelings and motives underlying Machiavellian behavioural strategies; narrative reports in a social dilemma situation. Int. J. Psychol. 2014, 49, 519-524. [CrossRef]

53. Maccormick, N. The Ethics of Legalism. Ratio Juris 1989, 2, 184-193. [CrossRef] 